Primljen / Received: 13.7.2016. Ispravljen / Corrected: 22.3.2017.

Prihvaćen / Accepted: 21.4.2017. Dostupno online / Available online: 10.6.2017.

\section{Analysing significance of key quality factors for management of construction projects}

Authors:

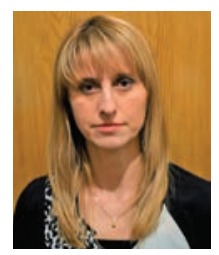

Žanesa Ljevo, MSc. CE University of Sarajevo Faculty of Civil Engineering zanesa.ljevo@gf.unsa.ba

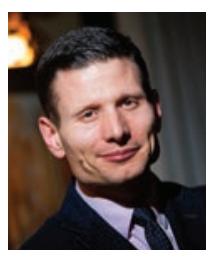

Assist.Prof. Mladen Vukomanović, PhD. CE University of Zagreb

Faculty of Civil Engineering mvukman@grad.hr

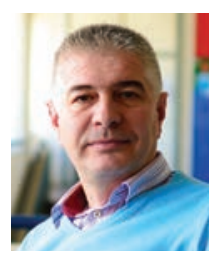

Assist.Prof. Nerman Rustempašić, PhD. Arh. University of Sarajevo Faculty of Architecture nermanr@af.unsa.ba
Žanesa Ljevo, Mladen Vukomanović, Nerman Rustempašić

Preliminary report

Analysing significance of key quality factors for management of construction projects

The study of key quality factors relating to construction project processes in Bosnia and Herzegovina and Croatia has revealed that these factors are not accepted similarly by investors, contractors/subcontractors and project managers/consultants/designers. The first four ranked factors are: coordination of participants, communication, expertise/ knowledge, and planning and control, with various priorities among the mentioned participants. The study has also revealed that the significance of individual quality factors differs during various phases of construction projects depending on differing management standpoints.

Key words:

key quality factors, project management, civil engineering, construction project

Prethodno priopćenje

Žanesa Ljevo, Mladen Vukomanović, Nerman Rustempašić

Istraživanje važnosti ključnih faktora kvalitete pri upravljanju građevinskim projektima

Istraživanje ključnih faktora kvalitete procesa građevinskih projakata u Bosni i Hercegovini te Hrvatskoj, pokazalo je da te faktore ne prihvaćaju jednako investitori, izvođači/podizvođači i voditelji projekta/konzultanti/projektanati. Prva četiri rangirana faktora su: koordinacija među sudionicima, komunikacija; stručnost/ znanje...; planiranje i kontrola, s različitim prioritetom unutar spomenutih sudionika. Istraživanje je nadalje pokazalo kako tijekom različitih faza građevinskog projekta važnost se pojedinih faktora kvalitete razlikuje s obzirom na različita upravljačka gledišta.

Ključne riječi:

ključni faktori kvalitete, upravljanje projektima, gradevinarstvo, gradevinski projekt

Vorherige Mitteilung

Žanesa Ljevo, Mladen Vukomanović, Nerman Rustempašić

Untersuchung des Stellenwerts von Schlüsselfaktoren für die Qualität im Bauprojektmanagement

Untersuchungen zu Schlüsselfaktoren für die Qualität der Prozesse von Bauprojekten in Bosnien und Herzegowina sowie in Kroatien haben gezeigt, dass diese Faktoren nicht einheitlich von Investoren, Unternehmern/Herstellern und Projektmanagern/Beratern / Projektanten aufgefasst wird. Die ersten vier rangierten Faktoren sind: Koordination zwischen den Beteiligten, Kommunikation; fachliche Kompetenz; Planung und Kontrolle, mit unterschiedlichen Stellenwerten für die einzelnen Beteiligten. Des Weiteren konnte festgestellt werden, dass sich der Stellenwert einzelner Qualitätsfaktoren in den Phasen des Bauprojekts für verschiedene Führungsblickwinkel ändert.

Schlüsselwörter:

Schlüsselfaktoren Qualität, Projektmanagement, Bauwesen, Bauprojekt 


\section{Introduction}

In the present-day activities of construction companies there is an increasing awareness that a strong link exists between the quality and long-term success on the market. Quality is considered important for modern organizations because it increases competitiveness and productivity, reduces costs and ensures a long-term cooperation with customers [1]. A contemporary company is under the influence of many factors, both from the external environment and from internal units of the company. In order to respond to market challenges in a timely manner, the company must improve the efficiency and effectiveness of its products, processes, and services, while also encouraging further education of its employees. The product quality has for a long time been defined as compliance of the features of the products and services with specifications listed in the contract or technical documentation. The quality of the project is defined as the fulfilment of the agreed project requirements [2, 3]. It is indicated in a relevant study that the risk, safety and quality are not direct problems, but are indirectly created by the organization of time and resources involved in the implementation of the project [4].

The quality management has become particularly important in the construction of structures [4]. If quality is managed in a proper manner, it can improve the project success rate and organizational viability [7]. Numerous studies indicate that project failure is often due to inadequate risk assessment and quality management [6]. According to Ogwueleki [7], project management can be improved through a process of quality management, i.e. the quality of the project can be improved through proper project management. Furthermore, the realization of the quality of final product can be controlled through the control of key quality factors. Therefore, this paper aims to investigate the importance of quality factors of the projectmanagement process at differentphases of the construction project as related to different participants, and provides ranking of the quality factors by different project participants. This will enable different stakeholders to use different factors and thus to select a distinctive approach for increasing quality of the delivered product. This paper presents the first phase of the research focusing on the importance of key quality factors during three phases of the construction project, and during the fourth phase, monitoring and control, which is conducted in parallel with all other activities on the project. The paper also provides an overview of literature about findings on the projects, project phases and project management, and also about the quality and impact of the quality of processes on the product quality. Furthermore, the research theme is explained and presented. The results of the research involving construction companies from Bosnia and Herzegovina $(\mathrm{BH})$ and Croatia are also presented. The final part of the paper provides discussion of results, and gives guidelines for further research in modelling the influence of quality in project management, which is to lead to additional quality improvements.

\section{Overview of literature}

\subsection{Project and phases of the project}

The project is an operation limited with time and costs, in the scope of which a set of defined results is achieved (field of fulfilment of project objectives) in accordance with appropriate standards and quality requirements [2]. Kerzner [8] defines a project as any number of activities and tasks characterized by a specific goal, compliance with some specifications, definite beginning and end, limited financial resources, consumption of resources (human and technical), and multifunctionality.

All projects, including construction projects, are characterized by some phases that differ according to different authors. This classification in typical phases of the project is given in Table 1. The phase of creating a concept implies the launch of the project and includes identification of needs and opportunities, determining the alternatives, and project organization. The planning / defining phase contains preparatory sketches and plans, detailed design, and creation of a complete plan. The execution / enforcement phase represents the execution and coordination of all activities and resources in order to complete the project. A phase / process that is parallel to all other phases is the monitoring and control phase that includes regular monitoring, controlling and recording of the activities that take place within the framework of the project, and providing a feedback. The completion phase of the project includes final activities and tasks to be implemented in order to achieve the project objectives that are interdependent [9-12]. In this research, the focus is placed on the following phases: start/ concept, planning/definition, performance/execution, monitoring and control. However, the project closure phase is not analysed, because it is not highly influenced by quality factors.

Table 1. Division of project into phases / processes

\begin{tabular}{|l|c|}
\hline \multicolumn{1}{|c|}{ Source - author } & \multicolumn{1}{|c|}{ Phases- processes of the project } \\
\hline Project Menagment Institute, 2013 [9] & $\begin{array}{c}\text { start / concept, planning / definition, performance / execution, monitoring and } \\
\text { control, project closure }\end{array}$ \\
\hline C.M.M. Chin, A.C. Spowage, E.H. Yap, 2012 [13] & initiation/ concept, definition, planning and closure \\
\hline PRINCE2, 2002 [14] & initiation, start, direction, control, management of delivery and finalization \\
\hline $\begin{array}{l}\text { eGovernment, 2006 [15] } \\
123 \text { method [16] }\end{array}$ & initiation, planning / preparation, execution, finalization / completion \\
\hline J. Highsmith, 2004 [17] & plan vision, speculation, research, adjustment, completion \\
\hline
\end{tabular}


The development of market relations, and compliance with the growing consumer demands to ensure better and more functional complementary products and information, have been included into the policy and objectives of the enterprises, and constitute a prerequisite for their development. So the quality of the product (regardless of the industry) depends on the quality of the process [8]. In construction industry, the quality of project management should directly influence the quality of the end product (building/structure).

\subsection{Quality and key quality factors of the project management process}

The quality of a product or service is determined by the relation between the wishes and needs of the users and its creation by the manufacturer [18]. It is obvious that the quality as a feature of a product / service has become extremely marketrepresented and promoted over the past twenty years. As such, today it is given a primary place among the indicators of market success of an organization, taking into account a number of measurable parameters such as productivity, profitability, liquidity, employment capacity, etc. Many researchers connect this phenomenon with an intensive trend of change in the attitude of customers towards quality. In order to stay on the market, the producers have had to adapt to this hypothesis. Current research shows that as many as $80-90 \%$ of customers / users are primarily concerned with the quality characteristics of the product. It is therefore not surprising that the last century is considered to be a century of quality, and quality is in turn considered as the most important phenomenon of our age [19].
Different authors define quality in many different ways and, according to ISO 9000: 2000 [18], quality is the degree to which a set of interdependent characteristics of the product / service meets the satisfaction of the customer. For Deming, quality is the solution to the problem, and for Juran, it is the appropriateness for use, while Corsby considers it to be a free feature, but not a gift [20].

Steps in quality management are: planning quality with the focus on the following criteria: setting quality objectives, identifying the customer, assessment of customer's needs, development of product features, development of process features, setting process control, and transfer to the operations. In the next step of assuring quality the focus is on selecting the object of control, choosing units of measurement, goal setting, creation of a sensor, measurement of actual effectiveness, interpretation of diversity and impact on diversity. In the scope of quality improvement it is necessary to prove the needs, identify the project, organize project teams, diagnose causes, prescribe corrective actions, deal with resistance to change, and ensure an overall control of the process in order to gain an advantage [9].

Two approaches to quality are now most often used in international practice. One is the use of a quality management system such as: ISO 9000, TQM (Total Quality Management), Six Sigma, Kaizen, 5S, Methodology of the twenty keys, while the other simply involves adopting quality in all aspects of the company's activities. In both cases, the first step is to analyse the key factors [21].

The key quality factors in different phases of the construction project, and the project management as such, are essential for determining the extent of influence these factors have on the quality of the constructed project/building.

Table 2. Quality factors

\begin{tabular}{|c|c|}
\hline Author & Quality factors \\
\hline C. Ogwueleka, 2013 & $\begin{array}{l}\text { program monitoring, employee involvement, expertise and training systems involved in the project, incomplete } \\
\text { or inaccurate cost estimates, focus on the customer / client, organizational skills, communication, continuous } \\
\text { improvement, interpretation of the expectations of the buyer / customer, quality policy, changes during the project } \\
\text { realization, availability of resources, project environment, implementation of relationship between time and cost, } \\
\text { uniqueness of the project, organizational skills }\end{array}$ \\
\hline $\begin{array}{l}\text { N.H. Husin, H. Adnan, } \\
\text { K. Jusoff, } 2008\end{array}$ & $\begin{array}{c}\text { expertise, knowledge and training, incorrect / incomplete pre-invoice, commitment to management, coordination } \\
\text { between project participants, changes / variations during the project, improper planning, inadequate project } \\
\text { schedule }\end{array}$ \\
\hline $\begin{array}{l}\text { D. Joaquin, D. Hernandez, } \\
\text { E. Aspinwall, } 2008\end{array}$ & continuous improvement, quality policy, availability of resources \\
\hline P.L.T. Hoonakker, 2006 & employee involvement, focus on the customer / client communication, interpretation of customer's expectations \\
\hline $\begin{array}{l}\text { E.A.P.C. Chan, C.M. Tam, } \\
\qquad 2000\end{array}$ & $\begin{array}{c}\text { supplier's quality management, project complexity, availability of resources, project environment, the uniqueness of } \\
\text { the project }\end{array}$ \\
\hline
\end{tabular}

Table 3. Key quality factors

\begin{tabular}{|c|c|c|c|c|c|}
\hline F1 & Planning and control & F5 & Top Management commitment & F9 & Quality policy \\
\hline F2 & Involvement, team work & F6 & Communication & F10 & Availability of resources \\
\hline F3 & Expertise, knowledge & F7 & Continuous improvement & \multirow{2}{*}{ F11 } & Supplier quality management \\
\hline F4 & Customer satisfaction & F8 & Coordination between project participants & & \\
\hline
\end{tabular}


Although many studies dealing with the influence of Quality Management factors (quality factors) were found during literature review conducted in the scope of this paper (Table 2), no study about explicit quality factors of project management process were actually found. In this research, project management is observed as a process and, at the end of each phase, the project delivers products (i.e. product quality factors) $[4,5,7,22,23]$. Factors presented in Table 2 have been identified as factors of the process (project management process) and product (deliverables), which were selected and amended (after analysis and consultation with university professors).

Furthermore, among all quality factors found in the literature, no information was found on the impact these factors have in different phases, and especially not from the different stakeholder's perspectives, which makes this study relevant for the current body of knowledge. In some cases, these factors are associated or compared with the factors that affect safety management of construction projects. Eleven quality factors were identified in previous research [12], cf. Table 3. Key quality factors presented in Table 3 are accepted and used in further research. The importance of quality factors affecting quality of the process, i.e. the quality of project management processes, is analysed.

\section{Research hypotheses}

Literature on project management identifies and supports three criteria or objectives for assessing the success of the project. These objectives are known as the "iron triangle" of time, cost and quality. For the first two objectives there are a number of exact methods for planning and control. The quality of the project, being the third dimension of the "iron triangle", is much more difficult to define, assess, plan, and control [25]. Turner [26] is one of several authors who have clearly defined the quality of the project, which consists of two dimensions: product quality and process quality. This represents the backbone of the research in which the impact of the process quality on the product quality will be studied. The paper assumes that different participants (Investor, Contractor / Subcontractor and Project Manager / Consultant / Architect / Designer) perceive differently the importance of key quality factors in different phases of the construction project, and rank them differently. For the above reasons the following hypotheses have been created:

H1: The ranking of key quality factors of the project management process differs depending on the individual stakeholder's perspective.

H2: During differentphases of the construction project the importance of quality factors differs depending on the individual stakeholder's perspective.

\section{Research methodology}

After the literature review, analysis and consultation with university professors, appropriate key quality factors were selected and used in this research. This work is based on a survey conducted in Bosnia and Herzegovina and Croatia, followed by the analysis of the results, and making conclusions [12]. The phases involving concept, defining and planning, execution, monitoring and control (running in parallel with the performance / execution phase), as well as the phases present in construction projects, were all taken into account in the questionnaires. The impact of the factors that were taken into account is obviously felt in all phases, and so the factors were not analysed in the closing phase of the project. The data obtained through study of literature and questionnaire results were used to analyse and defend the hypothesis, [12].

\subsection{Questionnaire and statistical methods}

The questionnaire was formed after selection of key quality factors for the construction sector in Bosnia and Herzegovina and Croatia. The first part of the questionnaire contained questions related to the key quality factors, and their importance was evaluated according to the Likert scale of assessment ( 1 - not at all important; ... 5 most important), after which each key quality factors was allocated a phase of the project (concept, defining and planning, execution, monitoring and control), as appropriate. The questionnaire was sent via e-mail by the means of the web application docs.google. com in the period from April to November 2014. (BH: April-July, Croatia: September-November) and 154 questionnaires were filled in (8,52\% of all questionnaires). The questionnaire consisted of five parts: the first part contained general questions, the second and third parts (the phases of the project) contained questions about project management, quality and success of the project. The fourth part analysed the quality factors, and the success factors were analysed in the fifth part. The ranking was conducted according to importance (Relative Importance Index - RII) and the respondents were grouped into investors, contractors, and project managers $[27,28]$. Ranking RII is made according to the expression (1):

$$
\mathrm{RII}=\frac{\sum \mathrm{w}}{\mathrm{AxN}}
$$

where:

$\Sigma \mathrm{w}$ - sum of grades given to each factor

A - max. assessment grade for each factor

$\mathrm{N}$ - total number of respondents.

$\mathrm{RIl}$ is in the interval $0 \div 1$. when used in the ordinal grading scale. As the value RII increases, the quality factor gains in importance.

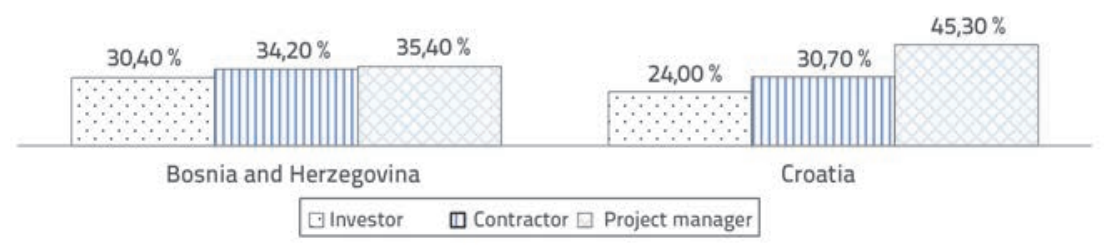

Figure 1. Participation of respondents by group 
This ranking method is preferred by many researchers. In fact, the method has been used by many authors in roughly similar cases, although none of the cases reported in literature fully corresponds to the case described in this study.

\subsection{Sample of respondents and results}

Construction project investors, civil engineers, and architects took part in the survey. Out of 154 questionnaires filled-in by the respondents, 79 were from Bosnia and Herzegovina and 75 from Croatia. The working experience of respondents is distributed as follows: below 5 years ( $5 \%$ ), from 5 to 10 years $(25 \%)$, from 11 to 15 years (31\%), from 16 to 20 years $(16 \%)$, and above 21 years (23 percent). This shows that a large proportion of respondents have over 10 years of working experience in construction industry, and their considerable experience has been of great value to this research. The survey shows that 68 percent of the respondents are experienced in both building / industrial and bridge / road projects. Figure 1 shows percentage of respondents by group: investor, contractor / subcontractor, project manager / consultant / architect in $\mathrm{BH}$ and Croatia.

\section{Discussion of results}

The quality-factor ranking results, and the analysis of importance of individual factors affecting quality management on the project, are presented in Table 4 by project phases and by groups (investor, contractor, project manager). In this case, the ranking of importance - RII is a measure of perceptions (strength of feeling).

The results of the research show that all participants from $\mathrm{BH}$ and Croatia consider that the most important factor for the quality of project management processes is the coordination between project participants (RII $=0.805$; 0.872), communication, expertise knowledge, and planning and control ... . According to ranking proposed by Ogwueleka [7] quality factors are ranked as follows: employee involvement, expertise knowledge, focus on customer/customer satisfaction, communication, which differs from the ranking factors obtained in the scope of this research.

Other rankings differ from one another. Thus, in Bosnia and Herzegovina investors believe that the most important factors are the top management commitment $(\mathrm{RII}=0.842)$,

Table 4. RII and ranking of quality factors from the perspective of various respondents

\begin{tabular}{|c|c|c|c|c|c|c|c|c|}
\hline \multirow[t]{4}{*}{ Participants in the project } & \multicolumn{2}{|c|}{ All respondents } & \multicolumn{2}{|c|}{ Investor } & \multicolumn{2}{|c|}{ Contractor } & \multicolumn{2}{|c|}{ Project manager } \\
\hline & BIH & RH & BIH & RH & BIH & RH & BIH & RH \\
\hline & RII & RII & RII & RII & RII & RII & RII & $R / l$ \\
\hline & Rang & Rang & Rang & Rang & Rang & Rang & Rang & Rang \\
\hline \multirow{2}{*}{ F1 - Planning and control } & 0,770 & 0,813 & 0,833 & 0,767 & 0,696 & 0,809 & 0,786 & 0,853 \\
\hline & 4 & 3 & 2 & 7 & 10 & 2 & 4 & 3 \\
\hline \multirow{2}{*}{ F2 - Involvement, team work } & 0,739 & 0,765 & 0,767 & 0,789 & 0,748 & 0,713 & 0,707 & 0,788 \\
\hline & 6 & 7 & 6 & 4 & 5 & 10 & 8 & 6 \\
\hline \multirow{2}{*}{ F3 - Expertise, knowledge ... } & 0,787 & 0,832 & 0,825 & 0,778 & 0,733 & 0,800 & 0,807 & 0,882 \\
\hline & 3 & 2 & 3 & 5 & 7 & 2 & 2 & 2 \\
\hline \multirow{2}{*}{ F4 - Customer satisfaction... } & 0,684 & 0,709 & 0,683 & 0,678 & 0,704 & 0,696 & 0,664 & 0,735 \\
\hline & 11 & 10 & 9 & 10 & 9 & 11 & 10 & 8 \\
\hline \multirow{2}{*}{ F5 - Top management commitment } & 0,739 & 0,725 & 0,842 & 0,767 & 0,674 & 0,722 & 0,714 & 0,706 \\
\hline & 6 & 9 & 1 & 7 & 11 & 9 & 7 & 10 \\
\hline \multirow{2}{*}{ F6 - Communication } & 0,792 & 0,816 & 0,783 & 0,778 & 0,785 & 0,800 & 0,807 & 0,847 \\
\hline & 2 & 3 & 5 & 5 & 2 & 2 & 2 & 4 \\
\hline \multirow{2}{*}{ F7 - Continuous improvement } & 0,716 & 0,789 & 0,683 & 0,800 & 0,711 & 0,774 & 0,750 & 0,794 \\
\hline & 10 & 5 & 9 & 1 & 8 & 5 & 5 & 5 \\
\hline \multirow{2}{*}{ F8 - Coordination between project partici. } & 0,805 & 0,872 & 0,817 & 0,800 & 0,778 & 0,887 & 0,821 & 0,900 \\
\hline & 1 & 1 & 4 & 1 & 3 & 1 & 1 & 1 \\
\hline \multirow{2}{*}{ F9 - Quality policy } & 0,724 & 0,728 & 0,683 & 0,733 & 0,741 & 0,739 & 0,743 & 0,718 \\
\hline & 8 & 8 & 9 & 9 & 6 & 7 & 6 & 9 \\
\hline \multirow{2}{*}{ F10 - Availability of resources } & 0,776 & 0,800 & 0,767 & 0,833 & 0,800 & 0,757 & 0,693 & 0,776 \\
\hline & 5 & 6 & 6 & 1 & 1 & 6 & 9 & 7 \\
\hline \multirow{2}{*}{ F11 - Supplier quality management... } & 0,719 & 0,680 & 0,733 & 0,622 & 0,763 & 0,696 & 0,664 & 0,700 \\
\hline & & 11 & 8 & 11 & 4 & 7 & 10 & 11 \\
\hline
\end{tabular}


planning and control (RII $=0.833)$, expertise and knowledge (RII $=0.825)$, coordination between project participants (RII $=0.817$ ). Contractors believe the most important factors are: availability of resources ( $\mathrm{RII}=0.800$ ), communication (RII $=0.785)$ coordination between project participants (RII $=0.815)$, and supplier quality management $(R \|=0.741)$.
Project managers believe that the most important factors are: coordination between project participants (RII $=0.821)$, expertise and knowledge ... (RII=0.807), communication (RII $=0.807)$, planning and control (RII =0.786). The difference in perspectives between investors and contractors, and investors and project managers, was observed in the factor "commitment

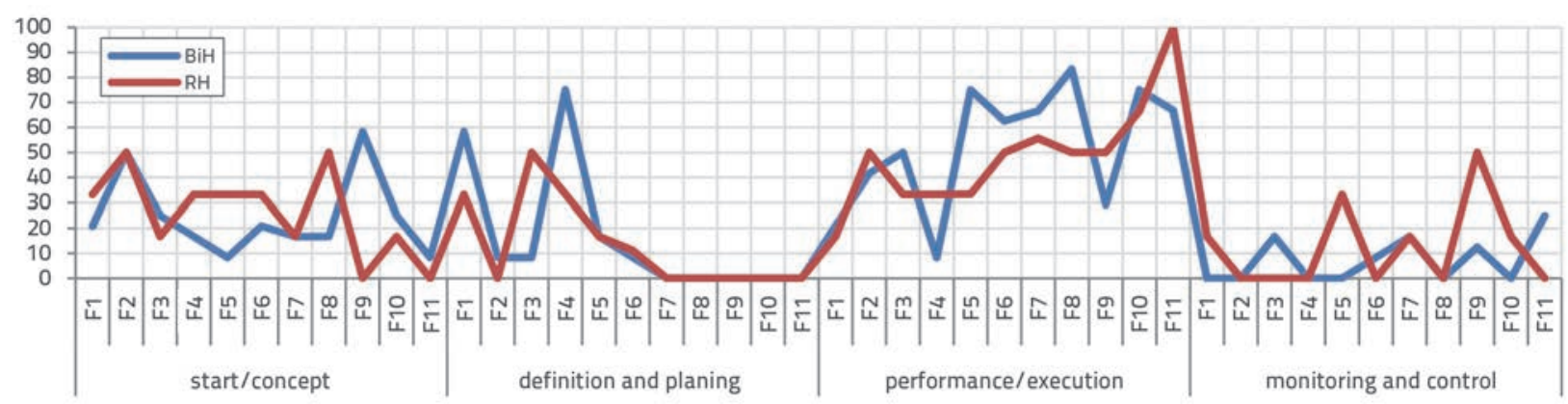

Figure 2. Importance of key factors at project phases, by Investors from BH and Croatia

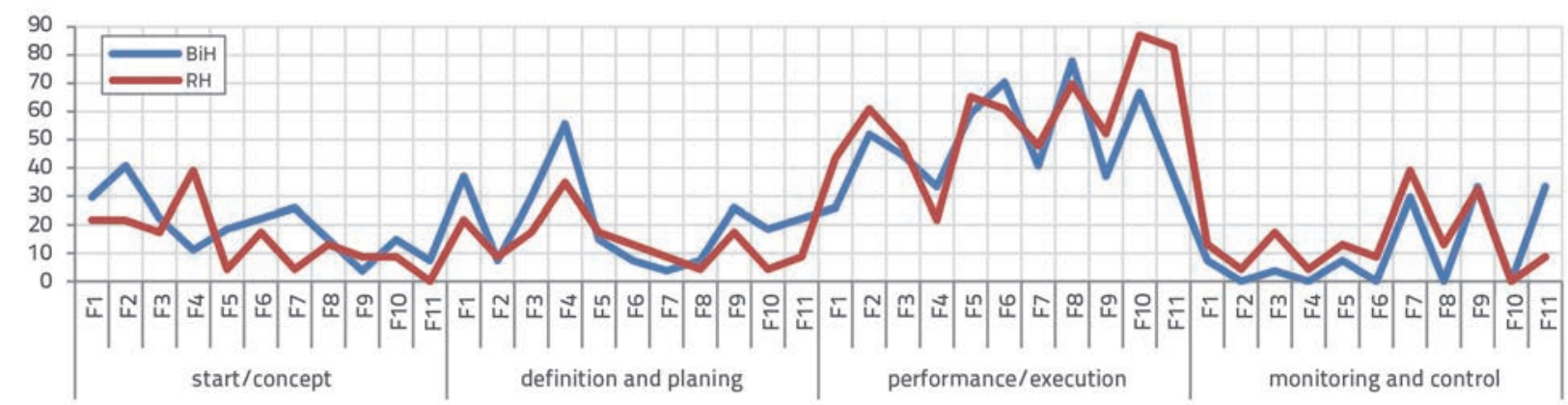

Figure 3. Importance of key factors at project phases, by Contractors... from BH and Croatia

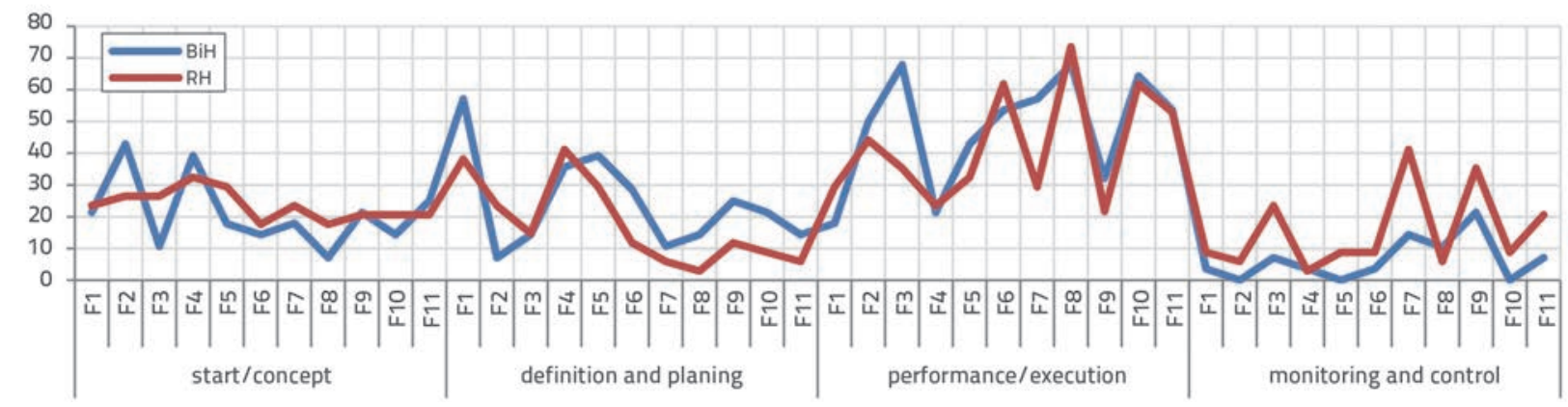

Charts 4.Importance of key factors at project phases by Project managers... from BH and Croatia

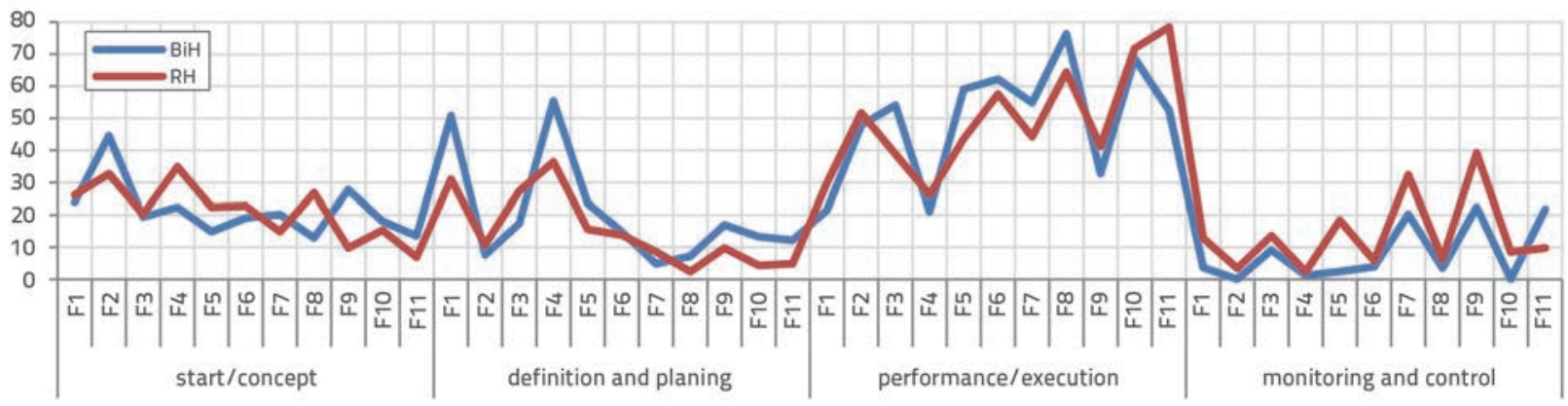

Figure 5.Importance of key factors at project phases by all respondents from BH and Croatia 
of top management". In Croatia, investors believe that the most important factors are continuous improvement $(\mathrm{R} I \mathrm{I}=$ $0.800)$, coordination between project participants (RII = 0.800), availability of resources (RII $=0.800)$, involvement, teamwork $\ldots$.. (RII = 0.789). Contractors believe that the most important factors are: coordination between project participants (RII $=0.887)$, planning and control (RII $=0.800)$, expertise and knowledge ... (RII = 0.800), communication (RII = 0.800), while project managers believe that the most important factors are coordination between the project participants (RII $=0.900$ ), expertise and knowledge ... (RII = 0.882), planning and control ( $R I I=0.853$ ) and communication ( $R I=0.847)$. The difference in perspective between investors and contractors, and between project managers and contractors, was observed in the factors "expertise, knowledge ... ". Also the difference in perspectives between investors and project managers occurred in the factor "coordination between the project participants".

Based on the analysis, it was concluded that there are significant differences in the understanding of the importance of each individual key quality factor, at specific phases of the project, between different participants in the project (Chart 2, 3, 4, 5).

All respondents (according to the management perspectives) from Bosnia and Herzegovina and Croatia consider that the phase of performance / execution is the most important phase for the quality of the process since the largest number of factors are assessed as critical to this phase, and the very execution phase is the longest in the life cycle of the project. In addition, the key factors evaluated are directly related to this phase. The differences in importance are visible both between individual factors and phases of the project, as well as between countries (Charts 2, 3, 4, and 5). All participants believe that the key factors are most important for the phase of performance / execution and, according to respondents from BH (Croatia) these factors are: F8, F10 and F6 (F11, F10 and F8). Respondents from Bosnia and Herzegovina (Croatia) consider that factors F2, F9 and F4 (F2, F4 and F9) are the most important for the concept phase. Factors F4, F1 and F5 (F4, F1 and F3) are the most important for the phase of defining and planning. Factors F8 F10, F6 (F11, F10 and F8) are the most important for the performance / execution, and factors F9, F11, F7 (F9, F7 and F5) are the most important for monitoring and control: (Chart 5).

\section{REFERENCES}

[1] Dolaček-Alduk, Z., Mikulić, D., Radujković, M.: Quality cost management model for construction projects, GRAĐEVINAR, 61 (2009) 2, pp. 147-159.

[2] IPMA (International Project Management Association), ICB IPMA Competence Baseline, Version 3.0., 2006.

\section{Conclusion and guidelines for future research}

The research results show that there is an obvious difference in ranking of key quality factors by different participants in the project in Bosnia and Herzegovina and Croatia. The top four ranked factors (F8 - coordination between project participants, F6 - communication, F3 - expertise, knowledge ..., F1 - planning and control) are the same in Bosnia and Herzegovina and in Croatia, but are not ranked in the same order, which shows that the difference in understanding the importance of factors is quite small in the countries in which the analysis was carried out (Table 4). The importance of each quality factor in the phases of the project has not been extremely different between the respondents from Bosnia and Herzegovina and Croatia, and they shared exactly the same opinion regarding the factors F6 - communication, F7 - continuous improvement, F8 - coordination between project participants, F10 - availability of resources, and F11 - supplier quality management, although the importance regarding other factors differed. According to their importance, the factors for a phase, such as conception, are F9, F2 for investors in $\mathrm{BH}$, and F2, F8 for investors in Croatia. As to contractors, these factors are $\mathrm{F} 2$ and $\mathrm{F} 1$ in $\mathrm{BH}$, and $\mathrm{F} 4, \mathrm{~F} 1$ in Croatia, while for project managers they are $\mathrm{F} 2, \mathrm{~F} 4$ in $\mathrm{BH}$ and F4, F5 in Croatia. The conducted research demonstrates that some participants in the project believe that the importance or ranking of key quality factors for the overall project (Table 4) and for project phases (Chart 2, 3, 4) differs to some extent. This also confirms that during certain phases of the construction project a different importance can be allocated to quality factors depending on a managerial perspective, which confirms the hypotheses presented in the paper.

The above mentioned results can help participants in construction projects to focus on the key quality factors that are marked as important for the phases in which they participate, or are rated as important for the entire project, and use them as indicators and, hence, direct the project towards achieving the final quality of the product (completed structure/building). This will save energy that would otherwise be needed for finding and identifying the factors required for efficient project management, and so a greater emphasis can be placed on meeting the previously defined objectives. Further research will be focused on modelling key quality indicators for both the processes and the final product, i.e. the completed structure/building.
[3] Dolaček-Alduk, Z., Mikulić, D., Radujković, M.: Upravljanje kvalitetom u projektno usmjerenom gradevinskom poslovanju, GRAĐEVINAR, 59 (2007) 3, pp. 209-218.

[4] Hoonakker, P.L.T. : Quality management in Construction Industry, Proceedings of ASQ World Conference on Quality and Improvement, Milwaukee, WI, USA, pp. 1 -9, 2006. 
[5] Husin, N.H., Adnan, H., Jusoff, K.: Management of Safety for Quality Construction, Journal of Sustainable Development, pp. 4147, 2008.

[6] Ling, F.Y.Y., Liu, M., Woo, Y.C.: Construction fatalities in Singapore, International Journal of Project Management, 27 (2009) 7, pp. 717726, https://doi.org/10.1016/j.jproman.2008.11.002

[7] Ogwueleka, A.C.: A Review of Safety and Quality Issues in the Construction Industry, Journal of Construction Engineering and Project Management, , 3 (2013) 3, pp. 42-48, https://doi. org/10.6106/JCEPM.2013.3.3.042

[8] Kerzner, H.: Project Management: A Systems Approach to Planning, Scheduling, and Controlling, Eighth Edition. Hoboken, John Wiley \& Sons, Inc, 2003.

[9] Project Menagment Institute, A Guide to the Project Management Body of Knowledge (PMBOK® Guide), Fifth Edition, Pennsylvania, USA, 2013.

[10] Ljevo, Ž., Vukomanović, M.: Characteristic project management model found in construction companies of Bosnia and Herzegovina, Technical Gazette, pp. 689-696, 2013.

[11] Ljevo, Ž.: Istraživanje modela poslovnog procesa graditeljske prakse u visokogradnji na primjeru privrednog subjekta, magistarski rad, Univerzitet u Sarajevu, Gradevinski fakultet, Sarajevo, 2011.

[12] Ljevo, Ž., Vukomanović, M., Rustempašić, N.: Assessing the influence of project management on quality in the construction industries of Bosnia and Herzegovina and Croatia, 12 $12^{\text {th }}$ International conference Organization, Technology and Management in Construction conference proceedings, 2015.

[13] Chin, C.M.M., Spowage, A.C., Yap, E.H.: Project Management Methodologies: A Comparative Analysis Participation, Journal for the Advancement of Performance Information \& Value, 4 (2012) 1, pp. 106-118.

[14] Office of Government Commerce, Managing Successful Projects with PRINCE 2. The Stationery Office, Norwich, UK, 2002.

[15] Vlada Republike Crne Gore, Metodologija za upravljanje eGOVERNMENT projektima, Republika Crna Gora, 2006.

[16] Method 123, http://www.method123.com/project-lifecycle.php

[17] J. Highsmith, Agile Project Management, Boston, Addison- Wesley, 2004.
[18] ISO Standard ISO 9001:2000, http://www.iso.org/

[19] Flyvbjerg, B.: Quality control and due diligence in project management: Getting decisions right by taking the outside view, International Journal of Project Management, 31 (2013) 5, pp. 760774, https://doi.org/10.1016/j.jpproman.2012.10.007

[20] QP Staff: Guru Guide, Six thought leaders who changed the quality world forever, Qality Progress, November, pp. 14-21, 2010.

[21] Yung, P., Yip, B.: Construction quality in China during transition: A review of literature and empirical examination, International Journal of Project Management, 28 (2010) 1, pp. 79-91, https://doi. org/10.1016/j.jproman.2009.03.003

[22] Chan, A.P.C., Tam, C.M.: Factors affecting the quality of building projects in Hong Kong, International Journal of Quality and Reliability Management, 17 (2000) 4/5, pp. 423-441, https://doi. org/10.1108/02656710010298445

[23] Joaquin, C.D., Hernandez, D., Aspinwall, E.: A framework for building quality into construction projects - Part I, Total Quality Management, pp. 1013-1028, 2008.

[24] Radujković, M., Vukomanović, M., Burcar Dunović, l.: Application of key performance indicators in southeastern European construction, Journal of Civil Engineering and Management, 16 (2010) 4, pp. 521-530, https://doi.org/10.3846/jcem.2010.58

[25] Marić, T., Radujković, M., Cerić, A.: Upravljanje troškovima, vremenom i kvalitetom izgradnje u građevinskim projektima, GRAEEVINAR, 59 (2007) 6, pp. 485-493, 2007.

[26] Turner, J.R.: Managing Quality. Chapter 16 In: Turner, Rodney, Simister, Stephen (Eds.), Gower Handbook of Project management, Gower Publishing, 2002.

[27] Radujković, M., Vukomanović, M., Dolaček-Alduk, Z.: The use of project management software in construction industry, Technical Gazette, 19 (2012) 2, pp. 249-258.

[28] Larsen, J.K., Shen, G.Q., Lindhard, S.M., Brunoe, T.D.: Factors Affecting Schedule Delay, Cost Overrun, and Quality Level in Public Construction Projects, Journal of Management in Engineering, 2016, https://doi.org/10.1061/(ASCE)ME.1943-5479.0000391 